\title{
Effect of Sodium Laurate on Ruminal Fermentation and Utilization of Ruminal Ammonia Nitrogen for Milk Protein Synthesis in Dairy Cows
}

\author{
A. N. Hristov, K. L. Grandeen, J. K. Ropp, and M. A. McGuire \\ Department of Animal and Veterinary Science, \\ University of Idaho, Moscow 83844
}

\begin{abstract}
A crossover design trial with 4 ruminally and duodenally cannulated lactating dairy cows was conducted to study the effect of sodium laurate on ruminal fermentation, nutrient digestibility, and milk yield and composition. The daily dose of sodium laurate $(0$, control or $240 \mathrm{~g} / \mathrm{cow}, \mathrm{LA})$ was divided in 2 equal portions and introduced directly into the rumen through the cannula before feedings. Ruminal samples (29 in $114 \mathrm{~h}$ ) were analyzed for fermentation variables and protozoal counts. Sodium laurate had no effect on ruminal $\mathrm{pH}$ and total and individual volatile fatty acids concentrations. Ruminal ammonia concentration, ammonia N pool size, and the irreversible loss of ammonia $\mathrm{N}$ were unaffected by treatment. Compared to control, protozoal counts were reduced by $91 \%$ by LA. Carboxymethylcellulase and xylanase activities of ruminal fluid were decreased (by 40 and 36\%, respectively), and amylase activity was not affected by LA compared with control. Flow of microbial $\mathrm{N}$ to the duodenum was reduced by LA. Dry matter intake and apparent total tract digestibility of dry matter, organic matter, crude protein, neutral detergent fiber, and acid detergent fiber were not different between the 2 treatments. Milk yield, fat-corrected milk yield, milk fat and protein concentrations and yields, and milk urea $\mathrm{N}$ content were not affected by treatment. Sodium laurate did not affect transfer of ruminal ammonia- ${ }^{15} \mathrm{~N}$ into bacterial or milk protein. In conclusion, LA at approximately $0.3 \%$ of the rumen weight reduced ruminal protozoal population and had a negative effect on fibrolytic activities of ruminal fluid and microbial protein flow to the intestine. Treatment had no other significant effects on ruminal fermentation, total tract digestibility, or transfer of ruminal ammonia $-{ }^{15} \mathrm{~N}$ into milk protein.
\end{abstract}

(Key words: dairy cow, lauric acid, protozoa, milk protein)

Received July 24, 2003.

Accepted December 19, 2003.

Corresponding author: A. N. Hristov; e-mail: ahristov@uidaho.edu.
Abbreviation key: AIA = acid-insoluble ash, APE = atom percent excess, CMCase = carboxymethylcellulase activity, FOR = fractional outflow rate, INDF = indigestible NDF, LA = sodium laurate, $\mathbf{P D A}=$ polysaccharide-degrading enzyme activities.

\section{INTRODUCTION}

The theoretical bases for improving $\mathrm{N}$ utilization in the rumen by elimination of protozoa are (1) protozoa are selectively retained in the rumen (Weller and Pilgrim, 1974; Leng et al., 1986; Punia et al., 1992); (2) by ingesting bacterial proteins, protozoa contribute significantly to microbial $\mathrm{N}$ recycling within the rumen (Coleman, 1975; Clark et al., 1992; Jouany, 1996); and (3) protozoa possess deaminative activity and their presence increases the extent of deamination of dietary amino acids (Jouany et al., 1988). Tamminga (1992) estimated that up to $50 \%$ of the dietary $\mathrm{N}$ is lost to the dairy cow through urinary $\mathrm{N}$ excretion. Of this $50 \%$, approximately $30 \%$ is lost due to inefficient $\mathrm{N}$ metabolism in the rumen. Therefore, the efficiency of ammonia utilization in the rumen is a central factor determining the economic cost and environmental impact of ruminant production. If not utilized for microbial protein synthesis, ruminal ammonia will be detoxified in the liver (Lobley et al., 1995) and a significant portion of it lost through urinary urea excretion. Microbial protein is a major source of amino acids for milk protein synthesis (NRC, 2001), thus serving as a transporter of $\mathrm{N}$ between the ammonia and milk $\mathrm{N}$ pools. Only a limited number of studies have attempted to determine the contribution of ruminal ammonia $\mathrm{N}$ to milk protein synthesis (Petri et al., 1988; Hristov and Ropp, 2003). Reduced protozoal counts in the rumen are usually associated with decreased ammonia concentration (Williams and Coleman, 1992), mostly resulting from a reduction in protozoal degradation of bacterial proteins (Broderick et al., 1991). Medium-chain saturated fatty acids are known to strongly inhibit ruminal protozoa (Newbold and Chamberlain, 1988; Matsumoto et al., 1991); protozoa were completely eradicated from the rumens of goats after $2 \mathrm{~d}$ of feeding C10:0 and C12:0 
acids (Matsumoto et al., 1991). Studies have indicated a strong inhibitory effect of coconut oil (lauric acid, C12:0, is a major constituent of coconut oil; CRC, 1988) on rumen ciliates (Sutton et al., 1983; Machmüler and Kreuzer, 1999; Dohme et al., 2000) and a significant reduction in ruminal ammonia concentration in the RUSITEC (Dohme et al., 1999). Decreased protozoal counts in the rumen usually result in increased microbial protein flow to the duodenum, although responses are variable and often not statistically significant (Williams and Coleman, 1992; Jouany, 1996; Koenig et al., 2000). Partial or complete defaunation of the rumen is frequently accompanied by lowered ruminal fiber degradation (Sutton et al., 1983; Dohme et al., 1999; Koenig et al., 2000). Machmüler et al. (2000), however, did not observe a depression in NDF/ADF digestibility in lambs receiving coconut oil compared with the unsupplemented control.

The objective of this study was to investigate the effects of sodium laurate (LA) on ruminal protozoa, fermentation and microbial protein synthesis in the rumen, nutrient digestibility, urinary $\mathrm{N}$ losses, milk yield and composition, and transfer of ruminal ammonia $\mathrm{N}$ into milk protein in dairy cows.

\section{MATERIALS AND METHODS}

\section{Animals and Feeding}

Four multiparous, late-lactation Holstein cows fitted with ruminal (Bar Diamond, Parma, ID) and simple Ttype duodenal (Ankom Technology, Fairport, NY) cannulae were used in the experiment. The duodenal cannulae were placed on the ascending duodenum, anterior to the pancreatic duct. The cows (average BW, $768 \pm$ $36.9 \mathrm{~kg}$; average DIM at the middle of the trial, $268 \pm$ $30.5 \mathrm{~d}$ ) were cared for according to the guidelines of the University of Idaho Animal Care and Use Committee and were grouped and subjected to the experimental treatments in a crossover design $(2 \times 2$ with 2 treatments and 2 periods, replicated with 4 cows). In a preliminary trial, 4 levels of LA, $0,0.2,0.4$, and $0.6 \%$ (as a percentage of an assumed rumen weight of $80 \mathrm{~kg}$ ), were tested to determine the effect of LA on general cow health, DMI, rumen $\mathrm{pH}$, and protozoal counts. Four cows were randomly assigned to one of the 4 treatments and treated twice (during the morning and afternoon feedings) for a period of $1 \mathrm{wk}$ before measurements were taken. Following the first 2 treatments with LA, the cow on the $0.6 \%$ level went off feed, ruminal $\mathrm{pH}$ increased above normal, and protozoa were completely eradicated. Similar effects, although less severe, were observed for $0.4 \% \mathrm{LA}$. The cow subjected to $0.2 \% \mathrm{LA}$ had a significantly reduced protozoal population, had a normal $\mathrm{pH}$, did not show any obvious signs of discom-
Table 1. Composition of the basal diet fed in the trial.

\begin{tabular}{|c|c|}
\hline Ingredient & $\%$ of $\mathrm{DM}$ \\
\hline Alfalfa hay, chopped ${ }^{1}$ & 28.3 \\
\hline Triticale silage $\mathrm{e}^{1}$ & 23.6 \\
\hline Barley grain, steam-rolled & 15.4 \\
\hline Corn grain, steam-flaked & 11.6 \\
\hline Cottonseed, whole with lint & 11.6 \\
\hline Solvent soybean meal, $48 \% \mathrm{CP}$ & 4.7 \\
\hline Blood meal & 2.6 \\
\hline Di-calcium phosphate & 0.2 \\
\hline Calcium carbonate & 0.3 \\
\hline Salt & 0.5 \\
\hline Mineral/vitamin premix ${ }^{2}$ & 1.2 \\
\hline \multicolumn{2}{|l|}{ Composition, \% of DM } \\
\hline $\mathrm{NEL}^{3}, \mathrm{Mcal} / \mathrm{kg}$ & 1.58 \\
\hline $\mathrm{CP}$ & 19.7 \\
\hline $\mathrm{NDF}$ & 39.6 \\
\hline $\mathrm{ADF}$ & 25.0 \\
\hline Nonfiber carbohydrates ${ }^{4}$ & 34.3 \\
\hline
\end{tabular}

\footnotetext{
${ }^{1}$ Triticale silage was $40 \% \mathrm{DM}, 11.1 \% \mathrm{CP}$, and $60.5 \% \mathrm{NDF}$. Alfalfa hay was $20.5 \% \mathrm{CP}$ and $41.1 \% \mathrm{NDF}$.

${ }^{2}$ Composition: 34.5 to $41.4 \% \mathrm{NaCl}, 26.9$ to $33.8 \%$ ground rice hulls, $27.9 \%$ barley, $0.24 \% \mathrm{MnSO}_{4}, 0.21 \% \mathrm{ZnO}_{3}, 0.052 \% \mathrm{Cu}_{2} \mathrm{SO}_{4}, 0.0014 \%$ $\mathrm{Fe}_{2} \mathrm{CO}_{3}, 0.0059 \% \mathrm{CaI}_{2} \mathrm{O}_{6} \cdot \mathrm{H}_{2} \mathrm{O}, 0.0010 \% \mathrm{CoCO}_{3}, 932 \mathrm{KIU} / \mathrm{kg}$ of vitamin A, $174 \mathrm{KIU} / \mathrm{kg}$ of vitamin $\mathrm{D}$, and $3.3 \mathrm{KIU} / \mathrm{kg}$ of vitamin $\mathrm{E}$.

${ }^{3} \mathrm{Control}$ diet. Based on the energy value of vegetable oil, dosing of $240 \mathrm{~g}$ of sodium laurate (LA)/d increased $\mathrm{NE}_{\mathrm{L}}$ content of LA to $1.61 \mathrm{Mcal} / \mathrm{kg}$ (NRC, 2001).

${ }^{4}$ Nonfiber carbohydrates derived from NRC (2001).
}

fort, and did not decrease DMI. As a result of this pretrial and based on previous in vitro experiments (Hristov et al., 2000c), a level of $240 \mathrm{~g} / \mathrm{d}$ per cow of LA (equivalent to $0.3 \%$ on an $80-\mathrm{kg}$ rumen base) was chosen for the experiment. Treatments were control (water) and LA (240 g of LA per cow per day). Sodium laurate was prepared as $1 \mathrm{~mol}$ of lauric acid (Parchem, White Plains, $\mathrm{NY}$ ) was reacted with $1 \mathrm{~mol}$ of $\mathrm{NaOH}$ (Fisher Scientific, Pittsburgh, PA) as $10 \mathrm{~N} \mathrm{NaOH}$ solution in water (final concentration of lauric acid was $0.2 \mathrm{~g} / \mathrm{mL}$ ). The LA solution was further diluted 1:1 with water (to a total dose of $2400 \mathrm{~mL} / \mathrm{d}$ per cow) and applied intraruminally twice a day, before the morning $(1200 \mathrm{~mL})$ and the afternoon (1200 mL) feedings. The basal diet (Table 1) was the same for both treatments and was fed as TMR twice a day at 0600 and $1800 \mathrm{~h}$. Based on the energy value of vegetable oil (NRC, 2001), supplementation with LA increased the $\mathrm{NE}_{\mathrm{L}}$ content of the basal diet by $1.9 \%$ compared with the water control (Table 1). Cows were fed at $95 \%$ of ad libitum intake determined before initiation of each experimental period. Diets were mixed in a Data Ranger (American Calan Inc., Northwood, NH). Refusals were collected and weighed daily; composited samples (per cow and per period) were analyzed for chemical composition; data were used to estimate actual intake of nutrients. Each experimental period consisted of $14 \mathrm{~d}$ of adaptation to the diet and $7 \mathrm{~d}$ of sampling. To minimize treatment carryover effect, on $d 1$ 


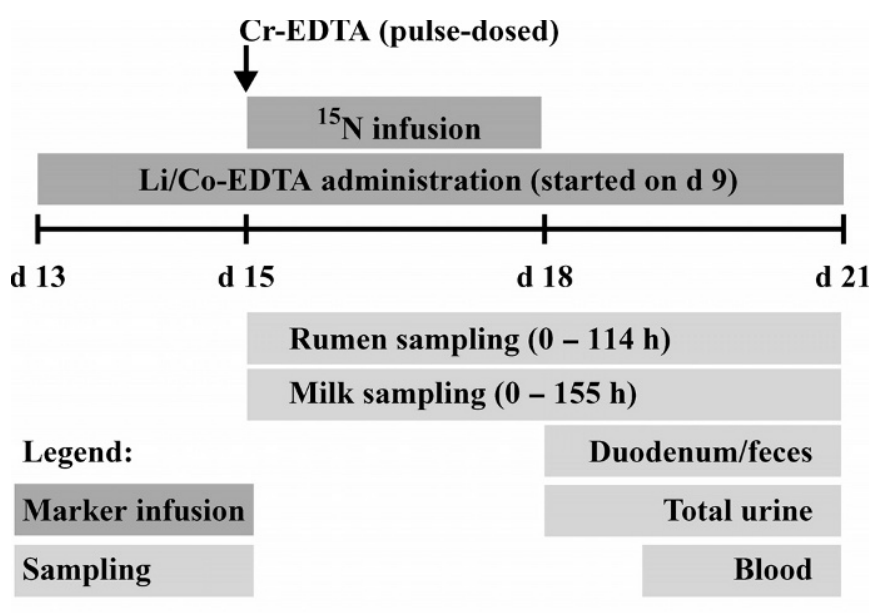

Experimental period (21 d)

Figure 1. Markers dosing and sampling schedule.

of each period the cows were inoculated with approximately $15 \mathrm{~kg} /$ head (replacing a similar amount of ruminal contents) whole ruminal contents obtained from 2 donor cows fed on the same basal diet.

\section{${ }^{15} \mathrm{~N}$-infusion, Sampling, and Related Analyses}

Ruminal ammonia $\mathrm{N}$ was labeled through a continuous 3 -d intraruminal infusion of 20 atom percent excess (APE) $\left({ }^{15} \mathrm{NH}_{4}\right)_{2} \mathrm{SO}_{4}$ (Cambridge Isotope Laboratories, Inc., Andover, MA) dissolved in distilled water at a final concentration of $26.4 \mathrm{mg} / \mathrm{mL}$ and infused into the rumen through the rumen cannula via a peristaltic pump (Technicon Instruments Corp., Tarrytown, NY). Figure 1 depicts a detailed marker infusion/dosing and sampling schedule for an experimental period. Due to uneven pump flow, the amount of solution infused per period varied between cows; in period 1 , cows received on average (mean $\pm \mathrm{SE}$ ) $3965 \pm 2.0 \mathrm{~mL}$ and in period $2-3883 \pm 13.6 \mathrm{~mL}$. Infusion was initiated at $0600 \mathrm{~h}$ on d 15 and terminated at $0600 \mathrm{~h}$ on $\mathrm{d} 18$ of each period. At $0600 \mathrm{~h}$ on $\mathrm{d} 1$ of the infusion, $200 \mathrm{~mL}$ of ${ }^{15} \mathrm{~N}$-solution was prime-dosed into the rumen of each cow.

Rumen sampling. Rumen samples were taken before $(0 \mathrm{~h}$, sample taken before the a.m. feeding) and 1 , $3,5,9,13,17,21,25,29,33,37,41,45,49,53,57,61$, $65,69,72,75,78,84,90,96,102,108$, and $114 \mathrm{~h}$ after initiation of the $\left({ }^{15} \mathrm{NH}_{4}\right)_{2} \mathrm{SO}_{4}$ infusion (Figure 1). Samples were taken from 4 locations in the rumen: ventral sac, reticulum, and 2 from the feed mat in the dorsal rumen (approximately $250 \mathrm{~g}$ each). The 4 samples were composited and squeezed through 2 layers of cheesecloth. Proteins in an aliquot of the filtrate were precipitated with $65 \%$ (wt/vol) TCA (5\% final concentration) and following centrifugation, supernatants were analyzed for ${ }^{15} \mathrm{~N}$ enrichment of ammonia $\mathrm{N}$ (Hristov et al., 2001). Bacterial pellets were isolated from the cheesecloth filtrate through differential centrifugations (an initial centrifugation at $400 \times g$ for $5 \mathrm{~min}$ and a subsequent centrifugation of the low-speed supernatant at $20,000 \times g$ for $15 \mathrm{~min}$ at $4^{\circ} \mathrm{C}$ ), freeze-dried, and analyzed for OM, NAN (Firkins et al., 1992), ${ }^{15} \mathrm{~N}$ enrichment (as for the ammonia), and purines. Purines were analyzed according to Zinn and Owens (1986) using the modified washing solution of Aharoni and Tagari (1991) and 0.6 $M \mathrm{HClO}_{4}$ (Makkar and Becker, 1999).

Milk sampling. Total milk output was measured and milk was analyzed for fat, true protein, and MUN during the last $7 \mathrm{~d}$ of each period (Washington DHIA, Burlington, WA). After initiation of the $\left({ }^{15} \mathrm{NH}_{4}\right)_{2} \mathrm{SO}_{4}$ infusion, cows were milked at 0 (background), 5, 10, $15,20,25,30,35,40,45,50,55,60,65,70,75,80,85$, $90,95,100,105,110,115,125,135,145$, and $155 \mathrm{~h}$ (Figure 1). At each milking, milk weights were recorded, and 2 milk samples were taken: one for analyses of milk fat, protein, and MUN and another for analysis of ${ }^{15} \mathrm{~N}$-enrichment of milk protein (Hristov and Ropp, 2003).

Calculations. Proportions of bacterial $\mathrm{N}$ originating from ruminal ammonia $\mathrm{N}$ were derived based on the plateau ${ }^{15} \mathrm{~N}$-enrichment of the $2 \mathrm{~N}$ pools (Shipley and Clark, 1972). Visual inspection of ruminal ammonia $\mathrm{N}$ and bacterial $\mathrm{N}^{15} \mathrm{~N}$-enrichment curves indicated that plateau enrichment was achieved between sampling time-points 1 and $72 \mathrm{~h}$ and 25 and $72 \mathrm{~h}$, respectively. The ${ }^{15} \mathrm{~N}$-enrichments within these periods were averaged, and the average values were used in the abovementioned calculations. The irreversible loss of ruminal ammonia $\mathrm{N}$ from the ammonia $\mathrm{N}$ pool was found as: $\left[{ }^{15} \mathrm{~N}\right.$ infusion rate $(\mathrm{g}$ atoms/day $\left.) \times 100\right] \div$ plateau ${ }^{15} \mathrm{~N}$ enrichment of ruminal ammonia N (APE) (Oldham et al., 1980). The microbial $\mathrm{N}$ leaving the rumen that originated from ruminal ammonia $\mathrm{N}$ was found: as microbial $\mathrm{N}$ flow $\times$ proportion of bacterial $\mathrm{N}$ originating from ammonia $\mathrm{N}$. The proportion of the irreversible ammonia loss incorporated into microbial protein leaving the rumen was found as $[$ (microbial $\mathrm{N}$ flow $\times$ proportion of bacterial $\mathrm{N}$ derived from ammonia $\mathrm{N}) \div$ irreversible loss of ammonia N] $\times 100$.

The cumulative amount of ${ }^{15} \mathrm{~N}$ excreted in milk protein was estimated as milk output for each milking interval (see Milk sampling) was multiplied by the TCAprecipitable $\mathrm{N}$ concentration of milk (see Hristov and Ropp, 2003 for precipitation procedure) and by its ${ }^{15} \mathrm{~N}$ enrichment. Due to differences in ${ }^{15} \mathrm{~N}$ dose, data were presented as percentage of ${ }^{15} \mathrm{~N}$ infused (for each individual cow) and were fitted to a 3-parameter Hill function of the type: $\mathrm{f}=\left(\mathrm{a} \times \mathrm{x}^{\mathrm{b}}\right) \div\left(\mathrm{c}^{\mathrm{b}}+\mathrm{x}^{\mathrm{b}}\right)($ SigmaPlot 8.0 regres- 
sion models library, SPSS Inc., Chicago, IL; Figure 3). In this case, $a$ represents the theoretical maximum of the ${ }^{15} \mathrm{~N}$ excreted with milk protein as a percentage of ${ }^{15} \mathrm{~N}$ infused in the rumen. Estimated maximum excretions for the 2 treatments were compared using the dummy variable regression technique (Hristov and Ropp, 2003).

\section{Nutrient Flow at the Duodenum and Total Tract Digestibility Determinations}

Nutrient flow. Flow of DM and nutrients at the duodenum was determined using the double-marker method of Faichney (1975). Lithium/Co-EDTA and indigestible NDF (INDF) were utilized as liquid and solid phase markers, respectively. Lithium/Co-EDTA (Udén et al., 1980) was applied to the diets at a daily dose equivalent to $4.2 \mathrm{~g}$ of Co/cow from $\mathrm{d} 9$ through the last day of each period (Figure 1). Indigestible NDF content of the diet and duodenal digesta were determined according to Rinne et al. (2002). Duodenal samples (300 $\mathrm{mL}$ per sampling) were taken at 0900,1500 , and 2100 $\mathrm{h}(\mathrm{d} 18)$, and at $0300,0600,1200,1800$, and $0000 \mathrm{~h} \mathrm{(d}$ 19 and 20 of each period (Figure 1). Samples were stored frozen at $-40^{\circ} \mathrm{C}$. After thawing, digesta was composited on a weight basis (per cow and period). The composited samples were separated into fluid and solid phases by filtering through a $100-\mu \mathrm{m}$ fabric (Sefar America Inc., Depew, NY). Both phases were freeze-dried, ground through a 1-mm sieve, and analyzed for OM, Co (Iris ICP atomic emission spectrophotometer, Thermo Jarrell Ash Corp., Franklin, MA), INDF, N, NAN, purines, $\mathrm{NDF}$, and ADF. Microbial protein flow to the duodenum was determined with purines as a microbial marker, assuming all purines present in duodenal digesta were of microbial origin. True digestibility of DM, OM, and NAN in the rumen was calculated as $\{1-[$ (duodenal flow of DM, OM, or NAN - duodenal flow of microbial DM, OM, or NAN) $\div$ intake of DM, OM, or NAN] $\} \times 100$.

Total tract digestibility. Total tract apparent digestibility of nutrients was determined with acid-insoluble ash (AIA, Van Keulen and Young, 1977) as an internal digestibility marker. Grab fecal samples (200 $\mathrm{g}$ per sampling) were collected from the rectum at the same sampling times used for duodenal digesta (Figure 1). Samples were composited per cow and period and oven-dried at $70^{\circ} \mathrm{C}$ to constant weight in an air-forced oven. Samples were ground through a 1-mm sieve and analyzed for OM, N, AIA, NDF, and ADF. Nutrient digestibility was calculated as described by Schneider and Flatt (1975).

\section{Other Analyses}

Feeds. Diets, alfalfa hay, and triticale silage were sampled once a week, and concentrate feeds were sam- pled once per period. Samples were dried at $70^{\circ} \mathrm{C}$ to constant weight and analyzed for ash, AIA, N (Hristov et al., 2001), and NDF and ADF (Ankom 200 Fiber Analyzer, Ankom Technology). A heat-stable amylase ( $\alpha$-amylase, EC No 232-560-9, Sigma Chemical Co., St. Louis, MO; Van Soest et al., 1991) was used in the NDF analysis; sodium sulfite was not used in the analysis.

Rumen. Aliquots from the cheesecloth filtrates (see Rumen sampling above) were immediately analyzed for $\mathrm{pH}$, and processed for analysis of ammonia, VFA, and polysaccharide-degrading [PDA; carboxymethylcellulase (CMCase), amylase, and xylanase] and deaminative enzyme activities as described (Hristov et al., 2000a). Proteolytic activity in ruminal fluid was determined using ${ }^{15} \mathrm{~N}$-labeled casein as a substrate according to Hristov et al. (2002). Ruminal filtrate samples taken between the a.m. and p.m. feedings $(1,3,5$, and $9 \mathrm{~h})$ and immediately before the p.m. feeding $(12 \mathrm{~h})$ during the course of sampling were composited and centrifuged at $400 \times g$ for $5 \mathrm{~min}$, and the supernatants were freezedried and analyzed for lauric acid concentration. Fatty acids were methylated using a 2-step procedure with sodium methoxide in methanol followed by methanolic $\mathrm{HCl}$ in acetyl chloride (Kramer et al., 1997). Methyl esters were analyzed using gas-liquid chromatography under conditions as described (Giesy et al., 2002). Lauric acid concentration in the control cows was subtracted from that in the LA cows, and the latter was expressed as a proportion of all fatty acids in ruminal fluid. Fractional outflow rate (FOR) of lauric acid in ruminal fluid was found as Ln-transformed concentrations were plotted vs. time after LA dosing. Ruminal samples were preserved and total protozoa counted as described (Hristov et al., 2000b).

Ruminal fluid outflow rate and volume. Chromium-EDTA (Udén et al., 1980) was used as a ruminal liquid passage rate marker and was pulse-dosed (equivalent of $2.5 \mathrm{~g} \mathrm{Cr} / \mathrm{cow}$ ) into the rumen of the cows at $0600 \mathrm{~h}$ on $\mathrm{d} 15$ of each period. Ruminal samples taken at $0,1,3,5,9,13$, and $17 \mathrm{~h}$ were filtered through cheesecloth, centrifuged at $20,000 \times g$ for 15 min at $4^{\circ} \mathrm{C}$, and the supernatants were analyzed for $\mathrm{Cr}$ concentration (Iris ICP atomic emission spectrophotometer). Fractional outflow rate of the ruminal fluid phase was found as Ln-transformed $\mathrm{Cr}$ concentrations were plotted vs. time. Volume of ruminal fluid was found as Cr dose was divided by the antilog of the regression intercept $(\mathrm{Cr}$ concentration at time $0 \mathrm{~h}$ ). The pool size of ruminal ammonia $\mathrm{N}$ was found as: ruminal volume $(\mathrm{L}) \times$ ammonia $\mathrm{N}$ concentration at time $0 \mathrm{~h}(\mathrm{~g} / \mathrm{L})$.

Urine. Urine was collected during the last $3 \mathrm{~d}$ of each period (Figure 1). Catheters and sample preparation are described elsewhere (Hristov et al., 2000b). Urine samples were analyzed for $\mathrm{N}$. 
Blood. On the last $2 \mathrm{~d}$ of each period, blood samples were taken from the jugular vein before $(0 \mathrm{~h})$ and 6 $\mathrm{h}$ after the morning feeding (Figure 1). Plasma was collected after centrifugation at $1500 \times \mathrm{g}$ for $40 \mathrm{~min}$, frozen at $-40^{\circ} \mathrm{C}$, and later analyzed for urea $\mathrm{N}$ (Urea Nitrogen kit, Ct. No. 640-8; Sigma Diagnostics, St. Louis, MO).

\section{Statistical Analyses}

Intake, ruminal fermentation, duodenal nutrient flows, digestibility, and urine data were analyzed using ANOVA assuming a crossover design. Rumen fermentation data were averaged per period and cow. Statistical analysis of total protozoal counts was performed on $\log _{10}$-transformed data. The model used was:

$$
\mathrm{Y}_{\mathrm{ijkl}}=\mu+\mathrm{G}_{\mathrm{i}}+\mathrm{C}(\mathrm{G})_{\mathrm{ij}}+\mathrm{P}_{\mathrm{k}}+\mathrm{D}_{\mathrm{l}}+\mathrm{e}_{\mathrm{ijk} \mathrm{k}},
$$

where $\mu$ is the overall mean, G, C, P, and D are group, cow, period, and treatment, and e is an error term under the usual assumptions for ANOVA (the error is distributed normally with mean $=0$ and a constant variance).

All data were analyzed using SAS (SAS, 1999).

\section{RESULTS}

Ruminal $\mathrm{pH}$ and ammonia concentration did not differ $(P>0.05)$ between treatments (Table 2). Ruminal $\mathrm{pH}$ decreased and ammonia concentration increased after feeding (data not shown) with no difference between treatments. Lowest average points of $\mathrm{pH}$ after feeding were similar between the control and LA and did not extend below 5.8. The size of the ammonia $\mathrm{N}$ pool was not different between treatments $(P<0.05)$. Total protozoal counts were reduced $(P<0.05)$ by $91 \%$ in LA compared with the control. Concentration of total and individual VFA and acetate to propionate ratio did not differ $(P>0.05)$ between treatments. Carboxymethylcellulase and xylanase activities in the fluid/small particles phase of ruminal contents were reduced $(P<$ 0.05 ) by 41 and $36 \%$ (respectively) in LA cows compared to the control. Amylase, deaminative, and proteolytic activities were not different $(P>0.05)$ between treatments. Fractional outflow rate of rumen fluid was also not affected $(P>0.05)$ by treatment. Rate of disappearance of LA from the rumen was similar $(P>0.05 ; t$ test) to the FOR of the fluid phase. Microbial N flow determined based on duodenal purines flow was $12 \%$ lower $(P<0.05)$ in LA than in control. Flow of microbial $\mathrm{N}$ derived from ammonia $\mathrm{N}$ was not different $(P>0.05)$ between the treatments. The efficiency of microbial synthesis in the rumen tended to be lower $(P<0.1)$ in LA compared with the control.
Intake of nutrients and total tract apparent digestibility of dietary DM, OM, N, NDF, and ADF did not differ $(P>0.05)$ between treatments (Table 3). Ruminal degradability of OM, N, and ADF did not differ $(P>0.05)$ between LA and the control. Ruminal degradability of NDF was $9 \%$ higher $(P<0.05)$ in LA compared with the control.

Milk yield, composition, MUN concentration, and the efficiency of dietary $\mathrm{N}$ utilization for milk protein synthesis were not different $(P>0.05)$ between treatments (Table 4).

Intake of $\mathrm{N}$ was numerically higher $(P>0.05)$ with the control than with LA (Table 5). Treatment did not affect $(P>0.05)$ urinary or fecal N excretion or N excretion as proportion of $\mathrm{N}$ intake. Within the limitations of balancing $\mathrm{N}$ in dairy cows (Spanghero and Kowalski, 1997), the difference between $\mathrm{N}$ intake and $\mathrm{N}$ excreted with feces, urine, and milk (12.8 and $11.2 \%$ of $\mathrm{N}$ intake, control and LA, respectively) would represent $\mathrm{N}$ deposition and gaseous (during fecal sample preparation), dermal, and scurf losses. Cows were in late lactation and gained weight (on average $28 \mathrm{~kg}$ ) during the trial.

Cows on both treatments received similar $(P>0.05)$ doses of ${ }^{15} \mathrm{~N}$ (Table 6). Approximately $46 \%$ (no treatment effect, $P>0.05$ ) of bacterial N was derived from ruminal ammonia N. Milk protein ${ }^{15} \mathrm{~N}$-enrichment peaked at $55 \mathrm{~h}$ after the ${ }^{15} \mathrm{~N}$ infusion was initiated, remained approximately constant for $20 \mathrm{~h}$, and began declining immediately $(3 \mathrm{~h})$ after the infusion was terminated (Figure 2). The irreversible loss of ammonia $\mathrm{N}$ from the ammonia $\mathrm{N}$ pool represented 42 and $38 \%$ (control and LA, respectively) of the dietary $\mathrm{N}$ intake and was not affected by treatment $(P>0.05)$. Approximately $34 \%$ of the ammonia produced in the rumen left the rumen as microbial $\mathrm{N}$ with no effect $(P>0.05)$ of treatment. Regression analysis of the cumulative ${ }^{15} \mathrm{~N}$ excretion curves (Figure 3) in milk protein showed no difference $(P>0.05)$ between treatments in the overall proportion of ${ }^{15} \mathrm{~N}$ dosed in the rumen excreted as milk protein $\mathrm{N}$ (8.8 and $9.2 \%$, control and LA, respectively).

\section{DISCUSSION}

Feeding fats to ruminants is commonly associated with decreased protozoal numbers in the rumen, but as it was shown by Doreau and Ferlay (1995), the response varied significantly depending on lipid source and fatty acid composition/saturation. Medium-chain, saturated fatty acids have strong antiprotozoal activities (Sutton et al., 1983; Newbold and Chamberlain, 1988; Matsumoto et al., 1991). Machmüler and Kreuzer (1999), Dohme et al. (1999), Sutter et al. (2000), and Dohme et al. (2000) clearly established the antiprotozoal properties of coconut oil, a major component of which is 
Table 2. Ruminal fermentation characteristics (least square means and associated SE).

\begin{tabular}{|c|c|c|c|c|}
\hline \multirow[b]{2}{*}{ Item } & \multicolumn{2}{|c|}{ Treatment $^{1}$} & \multirow[b]{2}{*}{$\mathrm{SE}$} & \multirow[b]{2}{*}{$P$} \\
\hline & Control & LA & & \\
\hline $\mathrm{pH}$ & 6.01 & 6.14 & 0.071 & NS \\
\hline Ammonia, $\mathrm{m} M$ & 12.0 & 11.8 & 0.52 & NS \\
\hline Ammonia $\mathrm{N}^{2}, \mathrm{~g}$ & 14.4 & 17.8 & 2.57 & NS \\
\hline Total protozoa ${ }^{3}\left(\times 10^{4}\right.$ cells $\left./ \mathrm{mL}\right)$ & $\begin{array}{c}111.4 \\
(6.05)\end{array}$ & $\begin{array}{c}9.8 \\
(4.98)\end{array}$ & $(0.017)$ & $* * *$ \\
\hline \multicolumn{5}{|l|}{ Volatile fatty acids, $\mathrm{m} M$} \\
\hline Acetate & 92.0 & 87.9 & 1.29 & NS \\
\hline Propionate & 20.5 & 19.7 & 0.79 & NS \\
\hline iso-Butyrate & 0.51 & 0.32 & 0.118 & NS \\
\hline Butyrate & 13.4 & 12.2 & 0.82 & NS \\
\hline iso-Valerate & 0.70 & 0.54 & 0.058 & NS \\
\hline Valerate & 0.86 & 0.70 & 0.079 & NS \\
\hline Total VFA & 127.9 & 121.4 & 3.02 & NS \\
\hline Acetate/Propionate & 4.51 & 4.51 & 0.132 & NS \\
\hline \multicolumn{5}{|c|}{ Polysaccharide-degrading activities ${ }^{4}$} \\
\hline CMCase & 50.4 & 29.8 & 0.46 & $* *$ \\
\hline Xylanase & 137.2 & 87.5 & 2.57 & $* *$ \\
\hline Amylase & 28.4 & 34.7 & 3.66 & NS \\
\hline Deaminative activity 5 & 3.35 & 3.46 & 0.084 & NS \\
\hline Proteolytic activity ${ }^{6}$ & 23.9 & 18.2 & 4.02 & NS \\
\hline Liquid phase $\mathrm{FOR}^{7}, \% / \mathrm{h}$ & 15.5 & 12.6 & 0.86 & NS \\
\hline Rumen volume, $\mathrm{L}$ & 107 & 132 & 5.7 & $\dagger$ \\
\hline LA FOR, \%/h & - & 12.2 & 2.17 & - \\
\hline $\mathrm{MN}^{8}$ flow, g/d & 228 & 201 & 3.7 & * \\
\hline MN from $\mathrm{NH}_{3}$ flow ${ }^{9}, \mathrm{~g} / \mathrm{d}$ & 102 & 91 & 4.6 & NS \\
\hline MN, g/kg OMTDR ${ }^{10}$ & 16 & 14 & 0.3 & $\dagger$ \\
\hline
\end{tabular}

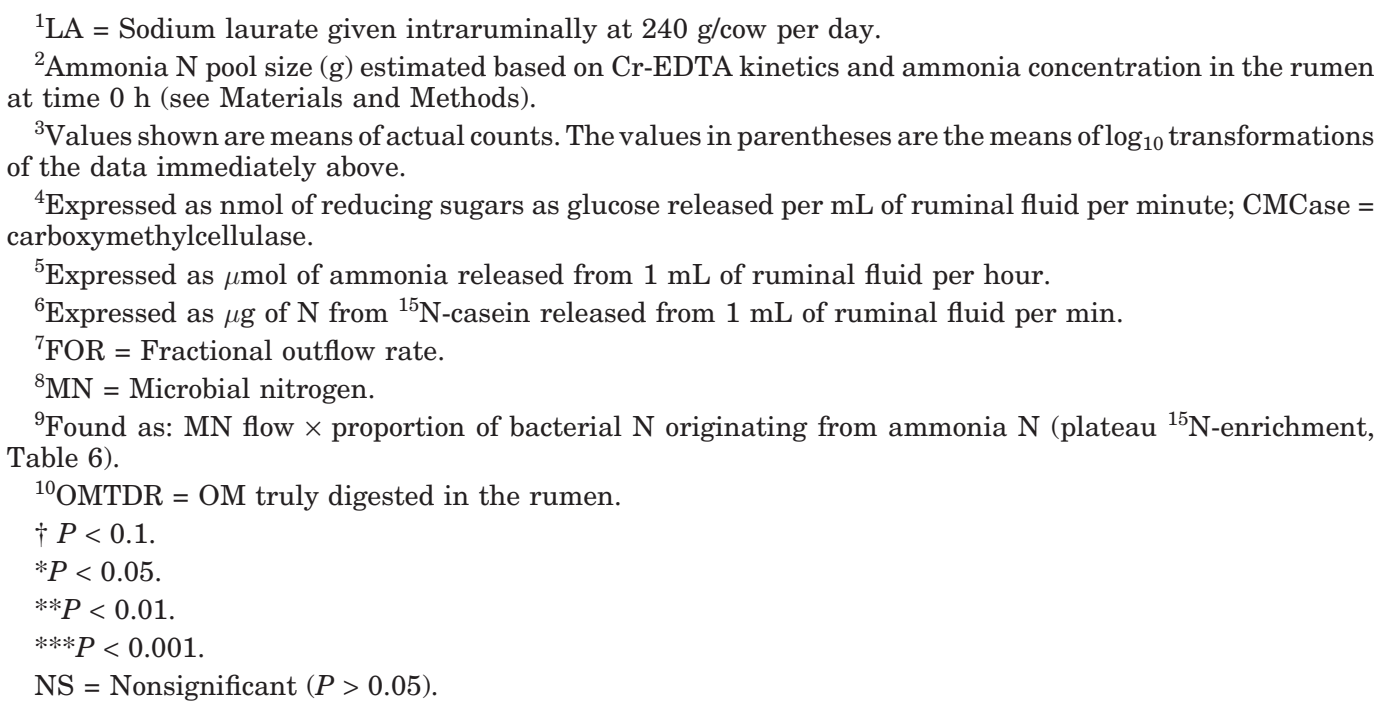

lauric acid (approx. 45\%; CRC, 1988). The main result of the present study is the significant reduction of protozoal counts in the rumen with the LA treatment. This is in confirmation with our in vitro observations where $\mathrm{LA}$ at $0.25,0.5$, or $1 \%$ (final medium concentration) completely eliminated protozoa (Hristov et al., 2000c), reduced ammonia concentration, compared with untreated control, by 70,73 , and $60 \%$, respectively, dramatically increased free amino acids concentration (on average 5.6 times), but also reduced bacterial incorporation of ${ }^{15} \mathrm{~N}$ by 19,26 , and $33 \%$, respectively.
The rate of reduction of lauric acid concentration in ruminal fluid was similar to the disappearance rate of the ruminal fluid, indicating insignificant microbial digestion. This finding is in accordance with the widely accepted view that, apart from biohydrogenation, there is little alteration of dietary fatty acids in the rumen (Demeyer and Doreau, 1999). Across sampling points, fatty acid concentration of ruminal fluid samples did not differ between the control and LA (8.4 vs. $7.7 \%$ of sample DM, respectively; $\mathrm{SE}=0.70$ and $P=0.551$ ). Average concentration of LA was higher $(P=0.007)$ in 
Table 3. Nutrient intakes and digestibility (least square means and associated SE).

\begin{tabular}{|c|c|c|c|c|}
\hline & \multicolumn{2}{|c|}{ Treatment $^{1}$} & \multirow[b]{2}{*}{ SE } & \multirow[b]{2}{*}{$P$} \\
\hline & Control & LA & & \\
\hline \multicolumn{5}{|l|}{ Intake, $\mathrm{kg} / \mathrm{d}$} \\
\hline $\mathrm{DM}$ & 24.4 & 23.1 & 0.70 & NS \\
\hline $\mathrm{OM}$ & 22.1 & 20.9 & 0.63 & NS \\
\hline $\mathrm{N}$ & 0.769 & 0.729 & 0.0219 & NS \\
\hline $\mathrm{NDF}$ & 9.7 & 9.2 & 0.28 & NS \\
\hline $\mathrm{ADF}$ & 6.1 & 5.8 & 0.17 & NS \\
\hline $\mathrm{NE}_{\mathrm{L}}{ }^{2}(\mathrm{Mcal} / \mathrm{d})$ & 38.6 & 37.3 & 1.13 & NS \\
\hline \multicolumn{5}{|c|}{ Ruminal digestibility, $\%$} \\
\hline DM, apparent & 54.7 & 57.0 & 0.48 & $\dagger$ \\
\hline DM, true & 66.7 & 67.9 & 0.46 & NS \\
\hline OM, apparent & 54.5 & 56.2 & 0.58 & NS \\
\hline $\mathrm{OM}$, true & 65.8 & 66.5 & 0.54 & NS \\
\hline $\mathrm{N}$, true & 80.3 & 83.3 & 1.07 & NS \\
\hline $\mathrm{NDF}$ & 52.2 & 56.7 & 0.68 & * \\
\hline $\mathrm{ADF}$ & 49.2 & 51.4 & 1.22 & NS \\
\hline \multicolumn{5}{|c|}{ Total tract apparent digestibility, $\%$} \\
\hline $\mathrm{DM}$ & 64.9 & 66.0 & 1.29 & NS \\
\hline $\mathrm{OM}$ & 66.3 & 67.3 & 1.21 & NS \\
\hline $\mathrm{N}$ & 70.0 & 70.2 & 0.92 & NS \\
\hline $\mathrm{NDF}$ & 53.8 & 53.9 & 1.37 & NS \\
\hline $\mathrm{ADF}$ & 52.1 & 51.7 & 1.43 & NS \\
\hline
\end{tabular}

${ }^{1} \mathrm{LA}=$ Sodium laurate given intraruminally at $240 \mathrm{~g} / \mathrm{cow}$ per day.

${ }^{2}$ Estimated (NRC, 2001).

$+P<0.1$.

$* P<0.05$.

NS $=$ Nonsignificant $(P>0.05)$.

LA than in the control ( 0.28 vs. $0.05 \%$, respectively). These data may, however, not be representative of the concentration of LA in whole ruminal contents since FA tend to concentrate on the feed particles (Harfoot and Hazlewood, 1997) and only a small proportion of $\mathrm{DM}$ in the rumen is associated with the fluid phase (Hristov and Broderick, 1996). The relatively low LA concentrations in ruminal fluid suggest that most of the exogenous LA added to the rumen was either absorbed onto ruminal particulate matter or assimilated by the ruminal microorganisms.

Table 4. Milk yield and composition (least square means and associated $\mathrm{SE})$.

\begin{tabular}{|c|c|c|c|c|}
\hline & \multicolumn{2}{|c|}{ Treatment $^{1}$} & \multirow[b]{2}{*}{$\mathrm{SE}$} & \multirow[b]{2}{*}{$P$} \\
\hline & Control & LA & & \\
\hline Milk yield, kg/d & 28.8 & 29.6 & 2.39 & NS \\
\hline $4 \%$ FCM yield, $\mathrm{kg} / \mathrm{d}$ & 26.3 & 26.8 & 2.06 & NS \\
\hline Milk fat, $\%$ & 3.44 & 3.38 & 0.025 & NS \\
\hline Yield, kg/d & 0.99 & 1.00 & 0.074 & NS \\
\hline Milk protein ${ }^{2}, \%$ & 2.93 & 2.79 & 0.028 & NS \\
\hline Yield, kg/d & 0.84 & 0.83 & 0.061 & NS \\
\hline Milk urea $\mathrm{N}, \mathrm{mg} / \mathrm{dL}$ & 24.2 & 22.1 & 1.60 & NS \\
\hline $\mathrm{N}$ efficiency ${ }^{3}, \%$ & 17.1 & 17.7 & 0.78 & $\mathrm{NS}$ \\
\hline
\end{tabular}

${ }^{1} \mathrm{LA}=$ Sodium laurate given intraruminally at $240 \mathrm{~g} / \mathrm{cow}$ per day.

${ }^{2}$ True protein.

${ }^{3} \mathrm{~N}$ efficiency $=($ milk protein yield $\div 6.38) \div \mathrm{N}$ intake.

NS $=$ Nonsignificant $(P>0.05)$.
The effect on protozoa observed in the present experiment was accompanied by decreased fibrolytic activities in the rumen and reduced microbial protein flow to the intestine, both indicative of inhibition of ruminal bacteria as well. Complete elimination of protozoa from the rumen, in most cases, leads to increased total ruminal bacterial counts and production and flow of bacte$\mathrm{rial} /$ microbial protein to the small intestine, likely reflecting reduced bacterial predation by protozoa and more available substrate for bacterial growth (Williams and Withers, 1991; Williams and Coleman, 1992; Koen-

Table 5. Nitrogen losses and plasma urea N (PUN) concentration (least square means and associated SE).

\begin{tabular}{lcccc}
\hline & \multicolumn{2}{c}{ Treatment $^{1}$} & & \\
\cline { 2 - 3 } & Control & LA & SE & $P$ \\
\hline N intake, g/d & 769 & 729 & 21.9 & NS \\
Total N excreted, g/d & 539 & 518 & 4.6 & $\dagger$ \\
Urine N & 309 & 301 & 6.1 & NS \\
As \% of total excreted & 57.1 & 58.3 & 0.61 & NS \\
As \% of intake & 40.2 & 41.5 & 1.92 & NS \\
Fecal N & 230 & 217 & 2.4 & $\dagger$ \\
As \% of total excreted & 42.9 & 41.7 & 0.61 & NS \\
As \% of intake & 29.9 & 29.8 & 0.92 & NS \\
PUN, mg/dL & 20.1 & 18.8 & 2.78 & NS \\
\hline
\end{tabular}

${ }^{1} \mathrm{LA}=$ Sodium laurate given intraruminally at $240 \mathrm{~g} / \mathrm{cow}$ per day. $\dagger P<0.1$.

NS $=$ Nonsignificant $(P>0.05)$. 
Table 6. ${ }^{15} \mathrm{~N}$ transformations (least square means and associated SE).

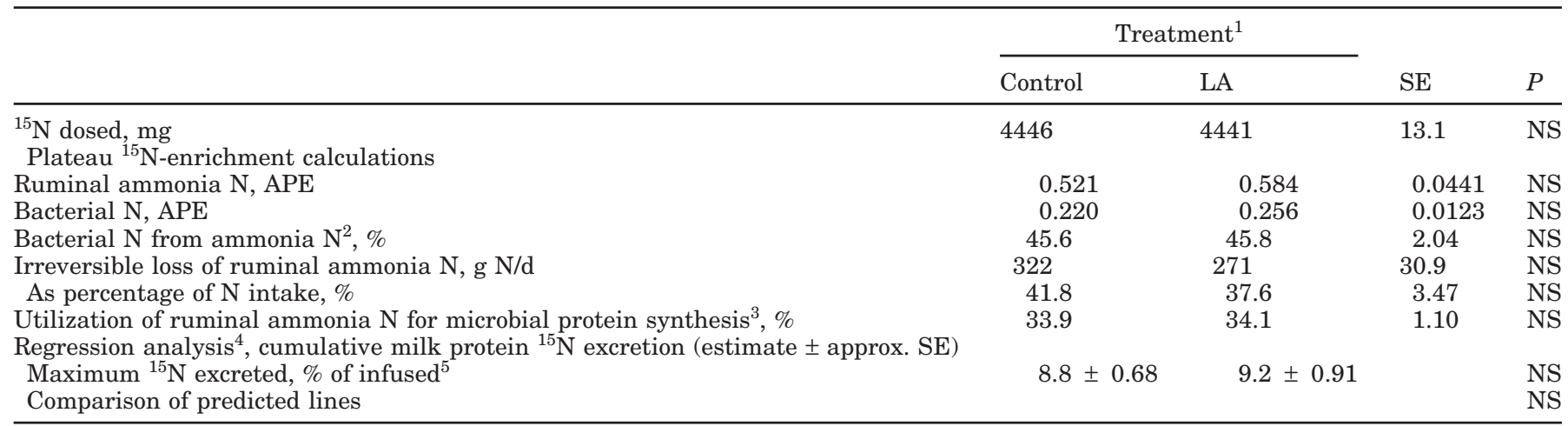

${ }^{1} \mathrm{LA}=$ Sodium laurate given intraruminally at $240 \mathrm{~g} / \mathrm{cow}$ per day.

${ }^{2}$ Calculated as: (Plateau ${ }^{15} \mathrm{~N}$-enrichment rumen bacteria $\div$ Plateau ${ }^{15} \mathrm{~N}$-enrichment rumen ammonia $) \times 100$.

${ }^{3}$ Proportion of the irreversible loss of ammonia $\mathrm{N}$ leaving the rumen as microbial $\mathrm{N}(\mathrm{MN})$. Found as [(MN flow $\times$ proportion of bacterial $\mathrm{N}$ derived from ammonia $\mathrm{N}) \div$ irreversible loss of ammonia $\mathrm{N}] \times 100$.

${ }^{4}$ Nitrogen-15 excretion in milk (mg) as percentage of ${ }^{15} \mathrm{~N}$ infused in the rumen (mg) fitted to a 3-parameter Hill function (see Materials and Methods for details).

${ }^{5}$ Theoretical maximum.

NS $=$ Nonsignificant $(P>0.05)$.

ing et al., 2000). Oldick and Firkins (2000) did not, however, find an effect of fat addition or degree of unsaturation on duodenal microbial $\mathrm{N}$ flow; the authors suggested that biohydrogenation and frequent feeding might have counteracted the effect of the fat. In the present study, protozoa were reduced from $1,114,000$ in the control cows to 98,000 cells $/ \mathrm{mL}$ in the LA-treated cows. The effect of LA was very consistent (as evident by the relatively small SE, Table 2) with all cows and throughout the sampling period; at any sampling point, none of the cows was completely protozoa-free. This effect on ruminal protozoa was accompanied by a $12 \%$

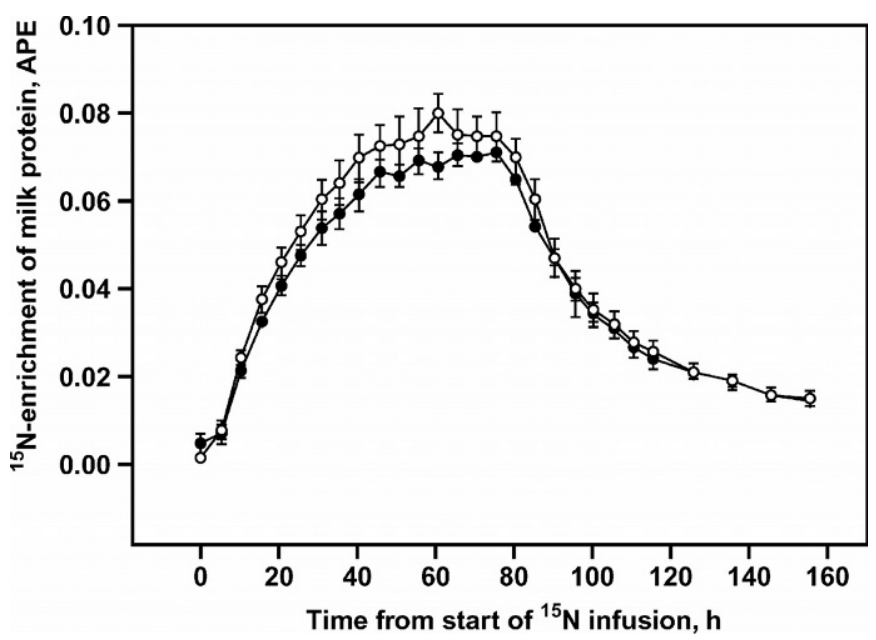

Figure 2. ${ }^{15} \mathrm{~N}$-enrichment of milk protein (means $\pm \mathrm{SE}$ ). Closed circles, control; open circles, sodium laurate. APE $=$ atom percent excess. reduction in microbial $\mathrm{N}$ flow as a result of LA treatment, suggesting LA may have inhibited microbial protein synthesis in the rumen to an extent greater than the potential positive effect on bacterial growth caused by the lowered protozoal counts. As pointed out by Williams and Coleman (1992) referring to an earlier work by Eadie and Shand (1981) and by Orpin (1977), antiprotozoal agents are not protozoa specific and can have an adverse effect on ruminal bacteria as well. Fatty acids, such as C8:0, C10:0, and C12:0, have strong anti-

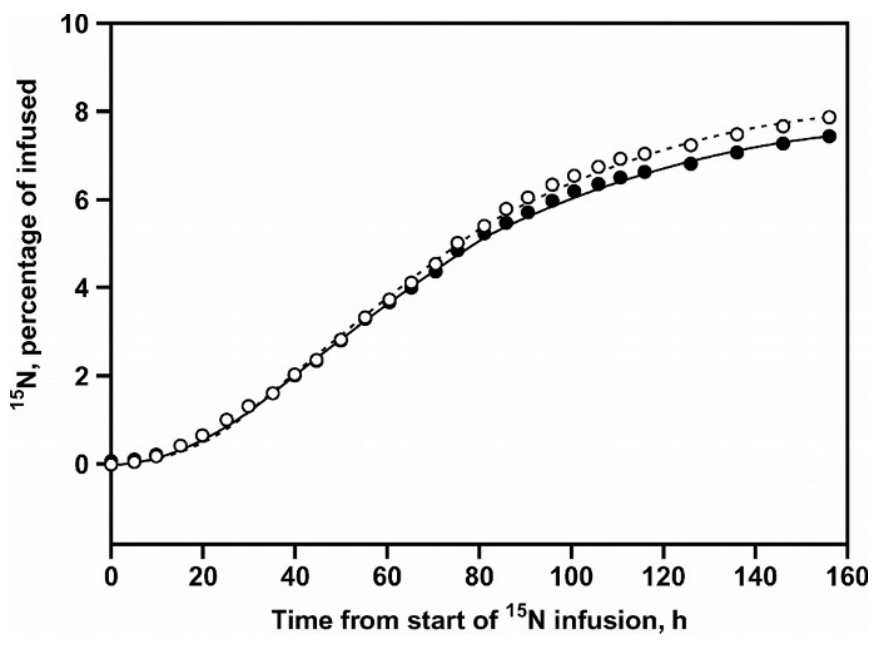

Figure 3. Cumulative excretion curves of ${ }^{15} \mathrm{~N}$ in milk protein as percentage of ${ }^{15} \mathrm{~N}$ infused intraruminally (measured and predicted values). Closed circles and solid line, Control, measured and predicted, respectively; open circles and dashed line, sodium laurate, measured and predicted, respectively. 
protozoal properties, but also negatively affect bacterial activities; others (C18:1, C18:2, and C18:3) inhibit protozoa, but have no effect on bacteria (Hristov et al., 2000c). It is also possible that the reduction in protozoal numbers in the present experiment was not sufficient to manifest in enhanced bacterial growth in the rumen and microbial $\mathrm{N}$ flow to the intestine. In estimating microbial $\mathrm{N}$ flow in this study, we used total $\mathrm{N}$ :purine ratio of ruminal fluid-associated bacteria as a standard. As indicated by Broderick and Merchen (1992), utilizing fluid bacteria N:purine ratios can lead to underestimation of microbial $\mathrm{N}$ flow due to the differences in ratios between fluid- and solid-associated bacteria and bacteria and protozoa. Perez et al. (1998) reported an average difference between liquid- and solid-associated bacteria purine: $\mathrm{N}$ ratio of $14 \%$ (1.89 vs. $1.66 \mu \mathrm{mol} / \mathrm{mg}$, respectively). The fractional contribution of liquid-associated bacterial purine bases to the total purine bases flow to the duodenum, however, varied considerably (from 29 to $81 \%$; Perez et al., 1998). Based on the differences in purine: $\mathrm{N}$ ratios in fluid- and solid-associated bacteria reported by Perez et al. (1998) and assuming 75\% of the bacterial mass in the rumen associated with the solid phase (Hristov and Broderick, 1996), microbial N flow to the duodenum was underestimated in the present study by $9.6 \%$. Not accounting for the significantly lower purine:N ratios in ruminal protozoa (Broderick and Merchen, 1992) would further underestimate microbial $\mathrm{N}$ flow.

The ruminal effects of the treatment were clearly related to inhibition of protozoal and bacterial activities. Inhibition of protozoa is often associated with reduced ruminal ammonia concentration (Williams and Coleman, 1992; Williams and Withers, 1993) presumably resulting from a reduction in protozoal digestion of bacterial proteins. Despite the $91 \%$ reduction in protozoal counts in this study, however, we did not observe an effect on ammonia concentration, ruminal ammonia $\mathrm{N}$ pool size, or deaminative activity of ruminal fluid. Consequently, blood plasma urea nitrogen and MUN were also unaffected by treatment. The rate of irreversible loss of ruminal ammonia $\mathrm{N}$ was also not affected by treatment, although it was $16 \%$ lower (numerically) with LA compared with the control. As a percentage of $\mathrm{N}$ intake, the irreversible ammonia $\mathrm{N}$ loss found in this study was lower than values reported by Oldham et al. (1980) for lactating dairy cows or Firkins et al. (1992) for dairy heifers. Nitrogen intake in these latter trials was, however, considerably lower (by approximately 50 and $85 \%$ ) than $\mathrm{N}$ intake in the present trial. The proportion of ammonia $\mathrm{N}$ produced in the rumen that was incorporated into microbial $\mathrm{N}$ and left the rumen averaged $34 \%$. Thus, the majority of the ammonia $\mathrm{N}$ produced in the rumen was not utilized by the ruminal microorganisms for protein synthesis, which was reflected in the relatively low overall utilization of dietary $\mathrm{N}$ for milk protein synthesis. The negative effect of LA on CMCase and xylanase activities and the lack of effect on the proteolytic and deaminative activities suggest that LA may have inhibited to a greater extent fibrolytic groups of bacteria and had negligible effect on proteolytic species. Suppression of endoglucanase activity, total bacterial counts, and cellulolytic and amylolytic species with $10 \%$ (DM basis) supplementation of coconut oil was reported by Dong et al. (1997) in the RUSITEC. Although protozoal counts and polysaccharide-degrading activities were reduced by LA in the present trial, VFA concentration was unaffected by treatment. Effect of defaunation on ruminal VFA concentration is not consistent, but in most cases concentration of VFA was lower in defaunated animals than in animals with normal fauna (Williams and Coleman, 1992), reflecting a reduction in microbial carbohydrate fermentation. Similar to our data, studies with coconut oil reported no effect of treatment on ruminal VFA concentration (Sutton, et al., 1983; Dohme et al., 1999; Machmüler et al., 2000).

Most data with defaunated animals indicate reduced $\mathrm{OM}$ and fiber degradability in the rumen (see Williams and Coleman, 1992). Similar to the microbial protein synthesis effect, data regarding ruminal degradability of OM/fiber fractions in animals with reduced flora are scarce. Sutton et al. (1983) observed a dramatic decrease in ruminal degradation of dietary NDF with coconut oil compared with the basal diet (12 vs. 50\%, respectively). Oldick and Firkins (2000) found decreased ruminal degradation of NDF with fat addition, independent of the degree of saturation, and reported no effect on ruminal protozoa. Similarly, Faichney et al. (2002) observed a dramatic decrease in ruminal neutral-detergent insoluble OM degradability with increasing dietary level of free fatty acids. Machmüler et al. (2000) found only a slight, numerical decrease (by 4\%) in total tract apparent digestion of dietary NDF with coconut oil (treatment that resulted in a $72 \%$ reduction in protozoal counts) compared with the control. Earlier work by Machmüler and Kreuzer (1999) reported a reduction in apparent OM digestibility by $2.5 \%$ coconut oil and concomitant reduction in ruminal protozoa (by $88 \%$ ), but no significant effect on NDF digestibility. In the present study, we also did not find a decrease in ruminal fiber degradability. Ruminal degradability was, however, unrealistically high compared with total tract fiber digestibility. Most likely, this was a result of underestimation of duodenal nutrient flows due to marker errors; relatively, treatment differences should not be affected. 
The proportions of bacterial $\mathrm{N}$ derived from ruminal ammonia $\mathrm{N}$ found in this study were within the range reported previously for alfalfa silage and hay diets, but lower compared with a urea-supplemented corn silage diet (Hristov and Broderick, 1996) and suggest that approximately half $(54 \%)$ of the ruminal bacterial $\mathrm{N}$ was derived from $\mathrm{N}$ sources other than ammonia. The outflow of microbial $\mathrm{N}$ derived from ammonia $\mathrm{N}$ followed the total microbial $\mathrm{N}$ flow pattern, but was only numerically reduced by LA compared with the control.

Our approach in estimating the proportion of ${ }^{15} \mathrm{~N}$ ammonia used for milk protein synthesis was based on the assumption that most of the ruminal ammonia that is not utilized for synthesis of microbial protein in the rumen will be detoxified in the liver and excreted as urea in the urine, and only a small proportion will be used for synthesis of nonessential amino acids, which can be used for various purposes and may or may not be eventually incorporated into milk proteins. Intravenous infusion of ${ }^{15} \mathrm{NH}_{4} \mathrm{Cl}$ in sheep showed that less than $4 \%$ of the net ${ }^{15} \mathrm{~N}$ transfer across the liver was as glutamate (Lobley et al., 1995) and 80 to $90 \%$ of the ${ }^{15} \mathrm{~N}$ infused appeared in urea (Lobley et al., 1996). Thus, if not captured as microbial protein in the rumen, most of the ammonia $\mathrm{N}$ absorbed through the rumen wall would be used for ureagenesis by the liver. Approximately 9\% of the ${ }^{15} \mathrm{~N}$ atoms introduced into the ruminal ammonia $\mathrm{N}$ pool were recovered in milk protein $\mathrm{N}$. Nitrogen-15 enrichment of bacterial $\mathrm{N}$ in the rumen declined rapidly after the isotope infusion was ceased and reached preinfusion values within $100 \mathrm{~h}$ (or $28 \mathrm{~h}$ after infusion was stopped; data not shown). Milk protein ${ }^{15} \mathrm{~N}$-enrichment also decreased rapidly within 100 to $110 \mathrm{~h}$ from the beginning of the infusion (Figure 2). Thus, the regression-derived theoretical maximum of ${ }^{15} \mathrm{~N}$ excreted in milk protein will closely represent the true amount of ruminal ammonia- ${ }^{15} \mathrm{~N}$ transferred into milk protein via microbial protein N. Apparently, N recycled from the tissues through various routes into milk protein will continue for a comparatively long period. Across treatments, the recovery of ruminal ammonia- ${ }^{15} \mathrm{~N}$ in milk protein in the present study (as proportion of ${ }^{15} \mathrm{~N}$ infused in the rumen) was approximately $34 \%$ lower compared with our previous estimates with diets containing similar CP and RDP (Hristov and Ropp, 2003). It appears that cows in the present trial utilized rumen ammonia less efficiently than the cows in our previous trial. An indication of this is the lower efficiency of conversion of feed $\mathrm{N}$ into milk protein $\mathrm{N}$ (17.4 vs. 20.8\%), higher urinary $\mathrm{N}$ excretion as proportion of $\mathrm{N}$ intake (40.9 vs. $36.2 \%$, respectively), and higher MUN concentrations in the present compared with the Hristov and Ropp (2003) trial. Milk urea N concentrations were relatively high in the present trial. The main reasons are perhaps the comparatively high CP content of the basal diet and the relatively low milk production of the experimental cows. The analytical procedure used to analyze for MUN (NIRS) may also be partially responsible for the high values (Peterson et al., 2003). Lauric acid induced numerically higher (5\%) recovery of ammonia${ }^{15} \mathrm{~N}$ than the control, but variability and limited number of experimental units did not allow the difference to be statistically proven. Recalculation of the data by Petri et al. (1988) shows that in the lactating goat, from 10.3 to $14.3 \%$ of the irreversible loss of ruminal ammonia $\mathrm{N}$ was recovered in milk protein via microbial protein.

\section{CONCLUSIONS}

Sodium laurate at approximately $0.3 \%$ of the rumen weight reduced ruminal protozoal counts by $91 \%$ and had a negative effect on ruminal fluid fibrolytic activities. Microbial protein flow to the duodenum was also reduced compared to the control. Treatment had no other significant effects on ruminal fermentation, total tract digestibility, milk yield and composition, or transfer of ruminal ammonia- ${ }^{15} \mathrm{~N}$ into milk protein. This study indicated that sodium laurate has a potential as an antiprotozoal agent but adverse effects on ruminal flora have to be circumvented.

\section{ACKNOWLEDGMENTS}

This study was partially supported by funds from the University of Idaho Seed Grant Program, the United Dairymen of Idaho, and a USDA/NRI/CGP grant (\#0103316). The authors would like to thank W. Price for assistance with statistical evaluation of the results and the staff of the Department of Animal and Veterinary Science Experimental Dairy for their conscientious care of the experimental cows.

\section{REFERENCES}

Aharoni, Y., and H. Tagari. 1991. Use of nitrogen-15 determinations of purine nitrogen fraction of digesta to define nitrogen metabolism traits in the rumen. J. Dairy Sci. 74:2540-2547.

Broderick, G. A., and N. R. Merchen. 1992. Markers for quantifying microbial protein synthesis in the rumen. J. Dairy Sci. 75:2618-2632.

Broderick, G. A., R. J. Wallace, and E. R. Ørskov. 1991. Control of rate and extent of protein degradation. Pages 541-592 in Physiological Aspects of Digestion and Metabolism in Ruminants. T. Tsuda, Y. Sasaki, and R. Kawashima (eds.) Academic Press Inc., San Diego, CA.

Clark, J. H., T. H. Klusmeyer, and M. R. Cemeron. 1992. Microbial protein synthesis and flows of nitrogen fractions to the duodenum of dairy cows. J. Dairy Sci. 75:2304-2323.

Coleman, G. S. 1975. The interrelationship between rumen ciliate protozoa and bacteria. Pages 149-164 in Digestion and Metabolism in the Ruminant. I. W. McDonald and A. C. I. Warner (eds.) University of New England Publishing Unit, Armidale, Australia. 
CRC. 1988. CRC Handbook of Chemistry and Physics 69th ed. R. C. Weast, M. J. Astle, and W. H. Beyer, eds. CRC Press Inc., Boca Raton, FL.

Demeyer, D., and M. Doreau. 1999. Targets and procedures for altering ruminant meat and milk lipids. Proc. Nutr. Soc. 58:593-607.

Dohme, F., A. Machmüler, B. L. Estermann, P. Pfister, A. Wasserfallen, and M. Kreuzer. 1999. The role of the rumen ciliate protozoa for methane suppression caused by coconut oil. Lett. Appl. Microbiol. 29:1-6.

Dohme, F., A. Machmüler, A. Wasserfallen, and M. Kreuzer. 2000. Comparative efficiency of various fats rich in medium-chain fatty acids to suppress ruminal methanogenesis as measured with RUSITEC. Can. J. Anim. Sci. 80:473-482.

Dong, Y., H. D. Bae, T. A. McAllister, G. W. Mathison, and K. J. Cheng. 1997. Lipid-induced depression of methane production and digestibility in the artificial rumen system (RUSITEC). Can. J. Anim. Sci. 77:269-278.

Doreau, M., and A. Ferlay. 1995. Effect of dietary lipids on nitrogen metabolism in the rumen: a review. Anim. Feed Sci. Technol. 43:97-110.

Eadie, J. M., and W. J. Shand. 1981. The effect of synperonic NP9 upon ciliate-free and faunated sheep. Proc. Nutr. Soc. 40:113A.

Faichney, G. J. 1975. The use of markers to partition digestion within the gastrointestinal tract of ruminants. Pages 277-291 in Digestion and Metabolism in the Ruminant. Proc. 4th Int. Symp. Ruminant Physiology. I. W. McDonald and A. C. I. Warner, ed. The University of New England Publishing Unit, Sydney.

Faichney, G. J., G. L. R. Gordon, R. J. Welch, and A. J. Rintoul. 2002. Effect of dietary free lipid on anaerobic fungi and digestion in the rumen of sheep. Aust. J. Agric. Res. 53:519-527.

Firkins, J. L., W. P. Weiss, and E. J. Piwonka. 1992. Quantification of intraruminal recycling of microbial nitrogen using nitrogen15. J. Anim. Sci. 70:3223-3233.

Giesy, J. G., M. A. McGuire, B. Shafii, and T. W. Hanson. 2002. Effect of dose of calcium salts of conjugated linoleic acid (CLA) on percentage and fatty acid content of milk fat in midlactation Holstein cows. J. Dairy Sci. 85:2023-2029.

Harfoot, C. G., and G. P. Hazlewood. 1997. Lipid metabolism in the rumen. Pages 382-426 in The Rumen Microbial Ecosystem. P. N. Hobson and C. S. Steward eds. Blackie Academic \& Professional, London, UK.

Hristov, A. N., and G. Broderick. 1996. Ruminal microbial protein synthesis in cows fed alfalfa silage, alfalfa hay or corn silage and fitted with only ruminal cannulae. J. Dairy Sci. 79:1627-1637.

Hristov, A. N., P. Huhtanen, L. M. Rode, T. A. McAllister, and S. N. Acharya. 2001. Ruminal metabolism of nitrogen from ${ }^{15} \mathrm{~N}$-labeled alfalfa preserve as hay or silage. J. Dairy Sci. 84:2738-2750.

Hristov, A. N., M. Ivan, and T. A. McAllister. 2000c. In vitro effects of common fatty acids on fermentation and protozoal numbers and activity in rumen fluid from cattle fed a barley-based diet. J. Anim. Sci. 78(Suppl. 1):275.

Hristov, A. N., M. Ivan, L. M. Rode, and T. A. McAllister. 2000a. Fermentation characteristics and ciliate populations in the rumen of cattle fed medium or high-concentrate barley-based diets. J. Anim. Sci. 79:515-524.

Hristov, A. N., T. A. McAllister, and K.-J. Cheng. 2000b. Intraruminal supplementation with increasing levels of exogenous polysaccharide-degrading enzymes: Effects on nutrient digestion in cattle fed a barley grain diet. J. Anim. Sci. 78:477-487.

Hristov, A. N., T. A. McAllister, Z. Xu, and C. J. Newbold. 2002. Comparison of three methods for determining proteolytic activity of ruminal fluid of cattle fed two levels of concentrate. J. Sci. Food Agric. 82:1886-1893.

Hristov, A. N., and J. K. Ropp. 2003. Effect of dietary carbohydrate composition and availability on utilization of ruminal ammonia nitrogen for milk protein synthesis in dairy cows. J. Dairy Sci. 86:2416-2427.

Jouany, J. P. 1996. Effect of rumen protozoa on nitrogen utilization by ruminants. J. Nutr. 126:1335S-1346S.

Jouany, J. P., D. I. Demeyer, and J. Grain. 1988. Effect of defaunating the rumen. Anim. Feed Sci. Technol. 21:229-265.
Kramer, J. K. G., V. Fellner, M. E. R. Dugan, F. D. Sauer, M. M. Mossoba, and M. P. Yurawecz. 1997. Evaluating acid and base catalysts in the methylation of milk and rumen fatty acids with special emphasis on conjugated dienes and total trans fatty acids. Lipids 32:1219-1228.

Koenig, K. M., C. J. Newbold, F. M. McIntosh, and L. M. Rode. 2000. Effects of protozoa on bacterial nitrogen recycling in the rumen. J. Anim. Sci. 78:2431-2445.

Leng, R. A., D. Dellow, and G. Waghorn. 1986. Dynamics of large ciliate protozoa in the rumen of cattle fed on diets of freshly cut grass. Br. J. Nutr. 56:455-462.

Lobley, G. E., A. Connell, M. A. Lomax, D. S. Brown, E. Milne, A. G. Calder, and D. A. H. Farningham. 1995. Hepatic detoxification of ammonia in the ovine liver: Possible consequences for amino acid catabolism. Br. J. Nutr. 73:667-685.

Lobley, G. E., P. J. M. Weijs, A. Connell, A. G. Calder, D. S. Brown, and E. Milne. 1996. The fate of absorbed and exogenous ammonia as influenced by forage or forage-concentrate diets in growing sheep. Br. J. Nutr. 76:231-248.

Machmüler, A., and M. Kreuzer. 1999. Methane suppression by coconut oil and associated effects on nutrient and energy balance in sheep. Can. J. Anim. Sci. 79:65-72.

Machmüler, A., D. A. Ossowski, and M. Kreuzer. 2000. Comparative evaluation of the effects of coconut oil, oilseed and crystalline fat on methane release, digestion and energy balance in lambs. Anim. Feed Sci. Technol. 85:41-60.

Makkar, H. P. S., and K. Becker. 1999. Purine quantification in digesta from ruminants by spectrophotometric and HPLC methods. Br. J. Nutr. 81:107-112.

Matsumoto, M., T. Kobayashi, and H. Itabashi. 1991. Effects of the absence of rumen ciliate protozoa on urinary allantoin excretion in goats. Anim. Sci. Technol. (Jpn.) 62:939-946.

Newbold, C. J., and D. G. Chamberlain. 1988. Lipids as rumen-defaunating agents. Proc. Nutr. Soc. 43:154A.

National Research Council. 2001. Nutrient Requirements of Dairy Cattle. 7th rev. ed. Natl. Acad. Press, Washington, D.C.

Oldham, J. D., I. Bruckental, and A. Nissenbaum. 1980. Observations on rumen ammonia metabolism in lactating dairy cows. J. Agric. Sci. 85:235-238.

Oldick, B. S., and J. L. Firkins. 2000. Effects of degree of fat saturation on fiber digestion and microbial protein synthesis when diets are fed twelve times daily. J. Anim. Sci. 78:2412-2420.

Orpin, C. G. 1977. Studies on the defaunation of the ovine rumen using dioctyl sodium sulphosuccinate. J. Appl. Bacteriol. 43:309-318.

Perez, J. F., J. Balcells, M. Fordevila, and J. A. Guada. 1998. Composition of liquid- and particle-associated bacteria and their contribution to the rumen outflow. Aust. J. Agric. Res. 49:907-914.

Peterson, A. B., R. A. Kohn, and E. Russek-Cohen. 2003. Comparison of analytical methods and the influence of milk components on milk urea nitrogen recovery. J. Dairy Sci. 86(Suppl. 1):221.

Petri, A., H. Müschen, G. Breves, O. Richter, and E. Pfeffer. 1988. Response of lactating goats to low phosphorus intake. 2. Nitrogen transfer from the rumen ammonia to rumen microbes and proportion of milk protein derived from microbial amino acids. J. Agric. Sci. 111:265-271.

Punia, B. S., J. Leibholtz, and G. J. Faichney. 1992. Rate of production of protozoa in the rumen and flow of protozoal nitrogen to the duodenum in sheep and cattle given a pelleted diet of lucerne hay and barley. J. Agric. Sci. 118:229-236.

Rinne, M., P. Huhtanen, and S. Jaakkola. 2002. Digestive processes of dairy cows fed silages harvested at four stages of grass maturity. J. Anim. Sci. 80:1986-1998.

SAS User's Guide Version 8, 1999. SAS Inst. Inc., Cary, NC.

Schneider, B. H., and W. P. Flatt. 1975. The Evaluation of Feeds through Digestibility Experiments. University of Georgia Press, Athens.

Shipley, R. A., and R. E. Clark. 1972. Tracer Methods for In Vivo Kinetics. Theory and Applications. Academic Press, New York, NY. 
Spanghero, M., and Z. M. Kowalski. 1997. Critical analysis of N balance experiments with lactating cows. Livest. Prod. Sci. 52:113-122.

Sutter, F., M. M. Casutt, D. A. Ossowski, M. R. L. Scheeder, and M. Kreuzer. 2000. Comparative evaluation of rumen-protected fat, coconut oil and various oilseeds supplemented to fattening bulls. 1. Effects on growth, carcass and meat quality. Arch. Anim. Nutr. 53:1-23.

Sutton, J. D., R. Knight, A. B. McAllan, and R. H. Smith. 1983. Digestion and synthesis in the rumen of sheep given diets supplemented with free and protected oils. Br. J. Nutr. 49:419-432.

Tamminga, S. 1992. Nutrition management of dairy cows as a contribution to pollution control. J. Dairy Sci. 75:345-357.

Udén, P., P. E. Colucci, and P. J. Van Soest. 1980. Investigation of chromium, cerium, and cobalt as markers in digesta. Rate of passage studies. J. Sci. Food Agric. 31:625-632.

Van Keulen, J., and B. A. Young. 1977. Evaluation of acid-insoluble ash as a natural marker in ruminant digestibility studies. J. Anim. Sci. 44:282-287.
Van Soest, P. J., J. B. Robertson, and B. A. Lewis. 1991. Methods for dietary fiber, neutral detergent fiber, and non-starter polysaccharides in relation to animal nutrition. J. Dairy Sci. 74:35833597.

Weller, R. A., and A. F. Pilgrim. 1974. Passage of protozoa and volatile fatty acids from the rumen of the sheep and from a continuous in vitro fermentation system. Br. J. Nutr. 32:341-351.

Williams, A. G., and G. S. Coleman. 1992. The Rumen Protozoa. Springer-Verlag Inc., New York, NY.

Williams, A. G., and S. E. Withers. 1991. Effect of ciliate protozoa on the activity of polysaccharide-degrading enzymes and fibre breakdown in the rumen ecosystem. J. Appl. Bacteriol. 70:144155.

Williams, A. G., and S. E. Withers. 1993. Changes in the rumen microbial population and its activities during the refaunation period after the reintroduction of ciliate protozoa into the rumen of defaunated sheep. Can. J. Microbiol. 39:61-69.

Zinn, R. A., and F. N. Owens. 1986. A rapid procedure for purine measurement and its use for estimating net ruminal protein synthesis. Can. J. Anim. Sci. 66:157-166. 